\title{
10 Environmental Innovations in Harmony of Sustainable Electricity Generation: An Experience of Combined-Cycle Power Plant of Priok, Indonesia
}

\author{
Dewi Permatasari, Flavianus Erwin Putranto, and Tri Tjahjonoputro
}

\begin{abstract}
This paper aims to promote a power generation company experience on non-renewable energy management within environmental preservation and commitment. The environmental commitment reflected on Sustainable Program to overall environmental aspects, social perspective also taken into account. Strategic Programs on each aspect shared in this paper consist of (1) Socialization of Environmental Policy and Environmental Team Incubation; (2) Solar Cell Utilization; (3) Replacement of Freon as Refrigerant for Operation Support; (4) Priok Vehicle-less in Red Zone Area; (5) Utilization of WWTP Sludge for Mixture Ingredients of Paving Block; (6) Solid Waste Preservation from Kali Japat Stream; (7) Utilization of Ablutions Water for Plants Watering; (8) Replacement of $\mathrm{NaOCl}$ as Water Biocide in Water Intake of CCPP 1-2; (9) 1,920 Endemic Crops Plantation in Setu Babakan - a Cultural Heritage Kampong of Betawi Community; (10) North Jakarta Local Community Development Through "Kampung Sehat". These ten noticeable programs in on going in 2016 with underlined purpose are to preserve and protect Jakarta's surround environment. Annual progress has also reported on Environmental Compliance and Beyond Assessment, commonly known as PROPER, under Directorate General of Control and Prevention of Environmental Damage, Ministry of Environment and Forestry, Ditjen PPKL - KLHK.
\end{abstract}

Index Terms-Environmental commitment, ten strategic programs, priok combined cycle of power plant, North Jakarta, environmental reporting, and proper.

\section{INTRODUCTION}

Electricity supply is one of the most vital demands of humanity. Therefore, massive energy sources in Indonesia are utilized to generate electricity, either renewable or non-renewable. For non-renewable energy source, it has known that can triggered environmental degradation [1]. This situation becomes one of top management concern, of how to satisfy electricity demand and simultaneously taking into account environmental sustainability.

PT. Indonesia Power - Generation and Service Unit (GSU) of Priok, as depicted in Fig. 1, is the Biggest Natural Gas Combined-Cycle Power Producer in Indonesia, connected with Jawa-Madura-Bali interconnection system. It operates

Manuscript received August 5, 2016; revised May 23, 2017. This program was a part of continuous improvement for green power plant behavior at PT Indonesia Power - Generation and Service Unit of Priok.

Dewi Permatasari is with Renewable and Non-Renewable Energy Sector, Indonesia (e-mail: dewi16permatasari@gmail.com).

Flavianus Erwin Putranto and Tri Tjahjonoputro are with PT. Indonesia Power - GSU Priok, Jakarta, Indonesia (e-mail: erwin.putranto@indonesiapower.co.id, tri.tjahjonoputro@indonesiapower.co.id). under PT. Indonesia Power Corporation, a subsidiary of State Electricity Company (PT. PLN Persero). GSU Priok situated in North Jakarta Area, with main supply zone of electricity in North Jakarta, East Jakarta, and Bekasi City - West Java. It operates three combined cycle block (1-2 and 3) with total installed capacity of $1,920 \mathrm{MW}$.

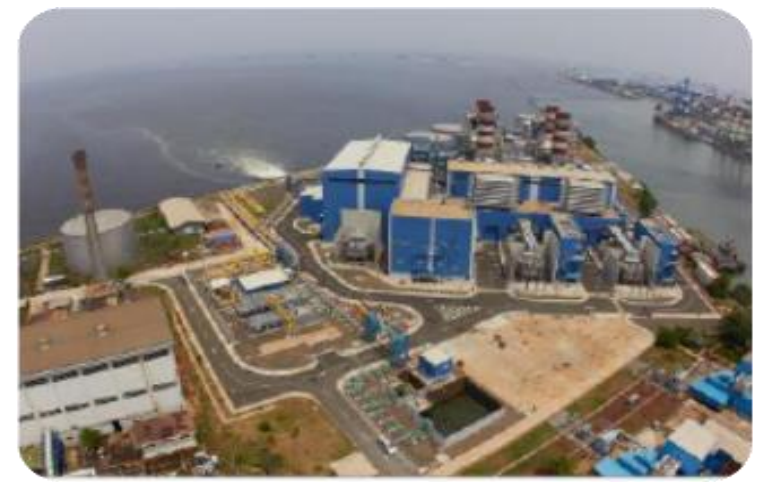

NGCC Power Plant of Priok consists of Block 1-2 (1180 MW) and Block 3

(740 MW). It generates electricity using natural gas as primary energy, supplied from Pertamina Hulu Energy Offshore North West Java (PHE ONWJ) - Nusantara Regas, and State Gas Company - Perusahaan Gas Negara (PGN) Fig. 1. Site of NGCC power plant of Priok.

Having vision to support corporate future to become World Class Services Company, NGCC Power Plant of Priok has also committed to contributes to Environmental Compliance and Beyond Assessment Program, PROPER, that awarded by Ministry of Environment and Forestry, for more than 6 years recently. As of 2015, NGCC Power Plant of Priok has increased the total score of achievement $82 \%$, and directly become the highest score in energy sector, in comparison with overall business unit.

This paper aims to introduce the environmental and social programs as non-partially concern from electricity operation perspective. The strategic programs that implemented have main goals to contribute to the environmental preservation, locally in North Jakarta Area, and possibly with positive impact in a global scale.

There are 10 (ten) essential programs, that covered every single aspect of environment. Those programs consist of (1) Socialization of Environmental Policy and Environmental Team Incubation; (2) Solar Cell Utilization; (3) Replacement of Freon as Refrigerant for Operation Support; (4) Priok Vehicle-less in Red Zone Area; (5) Utilization of WWTP Sludge for Mixture Ingredients of Paving Block; (6) Solid Waste Preservation from Kali Japat Stream; (7) Utilization of Ablutions Water for Plants Watering; (8) Replacement of $\mathrm{NaOCl}$ as Biocide in Water Intake of CCPP 1-2; (9) 1,920 Endemic Crops Plantation in Setu Babakan - a Cultural 
Heritage Kampong of Betawi Community; (10) North Jakarta Local Community Development Through "Kampung Sehat".

\section{MATERIALS AND MeTHODS}

\section{A. Materials}

Each program has specific requirement of materials, which simply divided into implemented program in GSU of Priok Generation Area and outside GSU of Priok Area. For instance, Solar Cell Utilization required solar cell panel, Replacement of Freon required Eco-friendly Freon R-134a, Vehicle-less Program required manual bicycle and its parking lot, Utilization of WWTP sludge required numbers of sludge from drying bed unit, Municipal Solid Waste from Kali Japat required a waste collection facility and its transportation facility, Utilization of Ablutions Water required additional watering line and supporting pump, Replacement of Chemical in Water Intake required numbers of chemicals (in this case is $\mathrm{NaOCl}$ replaced by Amine-Based chemicals), etc.

The other programs were implemented outside Priok Generation Site, such as Endemic Crops of Betawi, that currently consist of 25 species with specific environmental function, it was also required several plantation equipments. Then for Kampung Sehat Program, it required supporting facilities for each sub-program, such as waste collection facility for Jimpitan Sampah Program, health facility for education and health assistance.

\section{B. Methods}

This paper also demonstrates some methods used in several programs, which divided into talk show, technical energy and environment program, and social empowerment program. Firstly, for talk show, we used presentation and discussion, taking into account pre-test and post-test to measure basic knowledge. Secondly, the technical programs, it has clearly required calculation methods to support the absolute results of the program. Then finally for social empowerment program, we used interview and community testimonial mechanism, in some cases, questionnaire analysis are also taking into account.

Each program represents innovation in every aspect as referred to PROPER beyond compliance criteria. It begins with planning, doing, checking, and corrective action as in environmental management system fundamentally called as continuous improvement cycle.

\section{ENVIRONMENTAL COMPLIANCE AND BEYOND ASSESSMENT (PROPER) OVERVIEW IN INDONESIA}

\section{A. Regulatory Framework}

Population in Indonesia, mainly in Java Island, has exponentially increased year by year. It has many consequences, such as increasing of energy demand (water, electricity, etc.)[2], [3] which lead to degradation of environmental qualities. On the other hand, the government has to be responsible to the energy supply for social's welfare. Based on that, GSU of Priok, is one of national vital objects, has a mandatory to generate electricity together with other power generation companies in Jawa-Madura-Bali (JaMaLi) grid interconnection system.

As mentioned previously, GSU of Priok is non-renewable energy generation company, that committed to fulfill electricity demand and pursuing the environmental protection simultaneously. That commitment is something uneasy to follow, considering old paradigm in industrial sector was only concern about profit. Whereas when we taking into account the environmental aspects on operation point of view, it has clearly required additional concern on people and planet. In order to do that, the new paradigm required as 3P (People, Planet, and Profit).

As GSU of Priok has a business focus on power generation, it becomes a mandatory to contribute to support the government, through Ministry of Environment and Forestry, goals in environmental protection and preservation. That contribution assessed periodically in PROPER, regulated under Minister of Environment Regulation No. 03/ 2014 [4]. PROPER, for the recent two decades, has many transformations in their assessment criteria, begin with only company participation, and then currently become mandatory that legally required by law.

\section{B. Assessment Step}

Based on Minister of Environment Regulation No. 03/ 2014 (currently under Ministry of Environment and Forestry), the assessment of PROPER divided into several steps.

- Preparations step consists of preparation periodical data, lesson learned review, and environmental program inventory.

- Compliance Assessment, a step which energy sector should reporting data and evidences on water and air pollution control with its ambience monitoring, hazardous waste management, and environmental permitting (EIA, etc.). This step delivers the result into Comply (Blue Category) or Not Comply (Red Category-Nearby Comply; and Black Category-Totally Not Comply).

- Beyond Compliance Assessment. In this step, only companies that justified as " $100 \%$ Comply" can be continue to. There are several aspects assessed, such as Environmental Management System, Energy Efficiency, Hazardous Waste Management, Solid Waste Management, Emission Reduction, Water Efficiency and Wastewater Load Reduction, Biodiversity Protection, Community Development, and also Executive Summary. This step then delivers the result into "just comply" (back with Blue Category), "beyond comply" (Green Category), and for those company that passed the standard score, will be promoted to the Gold Candidate ("beyond comply with sustainable excellency").

\section{Environmental Goals}

As mentioned previously, GSU of Priok has successfully reached Beyond Compliance Criteria with The Best Green Category, in comparison with overall business unit [5]. We dedicated to improve the environmental compliance with sustainable strategic programs in energy conservation and 
environmental concern, together with local community involvement.

\section{RESULTS AND DisCUSSIONS}

As we already stated, we dedicated 10 (ten) essential programs that covered more than beyond criteria requirement It has begun with employee capacity building, technical effort to reduce the environmental impact, and social development program. For some technical program, we also consider the community involvement, such as Kali Japat Municipal Waste Management Program, and Setu Babakan Endemic Plantation Program. Overall programs have been successfully held and possibly can be either continued or developed as sustainable program.

\section{A. Environmental Management System: Talk Show on Environmental Policy and Employee Capacity Building through Team Incubation}

\section{Talk Show on Environmental Policy}

One of the new-launch programs on Environmental Management System (EMS) is Talk Show about Environmental Policy in GSU of Priok. It has a purpose to build a certain communication between the top management and all employees about the importance of environmental preservation surrounding the power plant site. The Talk Show, situated in main meeting room, was directly presented by General Manager, within over $70 \%$ of non-operator employee has participated [6]. The situation at the moment depicted on Fig. 2.

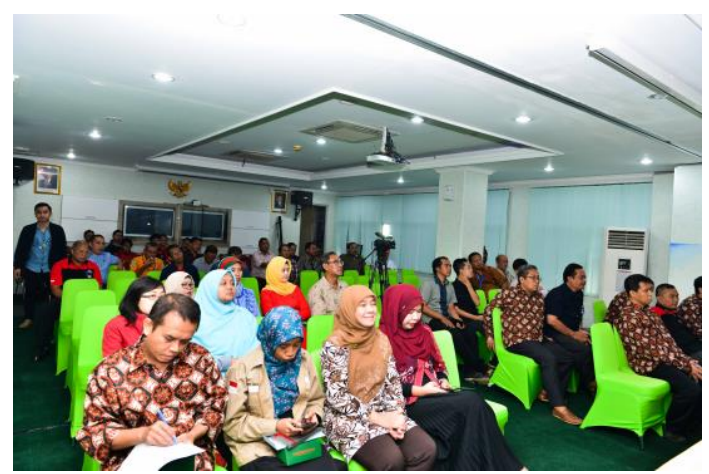

Fig. 2. Situation during talk show on introducing environmental policy.

During the Talk Show, we conducted discussion to improve their interest on environmental aspects. The feedback was measured by testing several basic questions on Pre- and Post Test. It was clustered based on employees division, such as Health, Safety and Environment (HSE), Engineering (ENG), and Administration (ADM), as it depicted on Fig. 3 to Fig. 5.

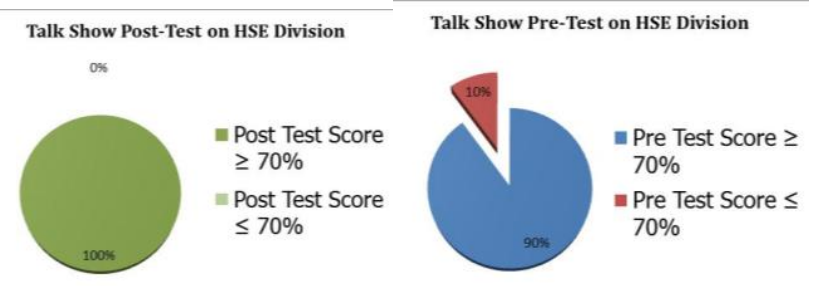

Fig. 3. Pre-test and post-test result on HSE team [6].

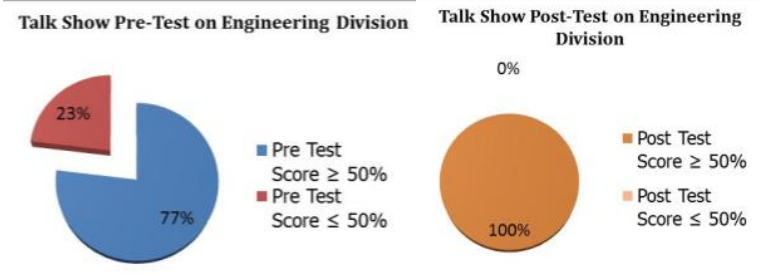

Fig. 4. Pre-test and post-test result on engineering team [6].

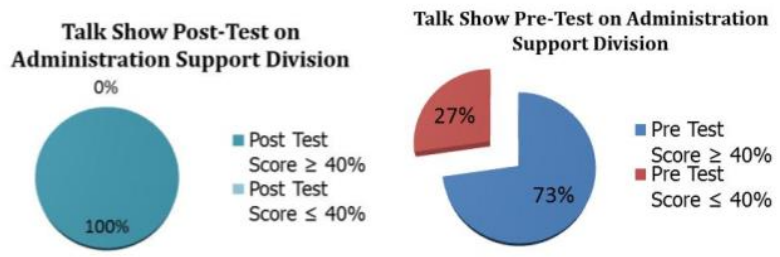

Fig. 5. Pre-test and post-test result on administration support team [6].

It is clearly shown on Fig. 3 to Fig. 5, that every division has different basic knowledge depend upon their daily job description. It concludes that introducing the environmental policy to stimulate their concern and behavior is possible, considering the post test result is $100 \%$ success. Nevertheless, evaluation and improvement of the program has also to be considered in the future [7].

\section{Environmental Incubation}

Other EMS program shared in this paper is Employee Capacity Building through Team Incubation. About twelve in charge person has already incubated regularly and given specific task for 2016 implementation. Evidence during incubation is shown in Fig. 6.

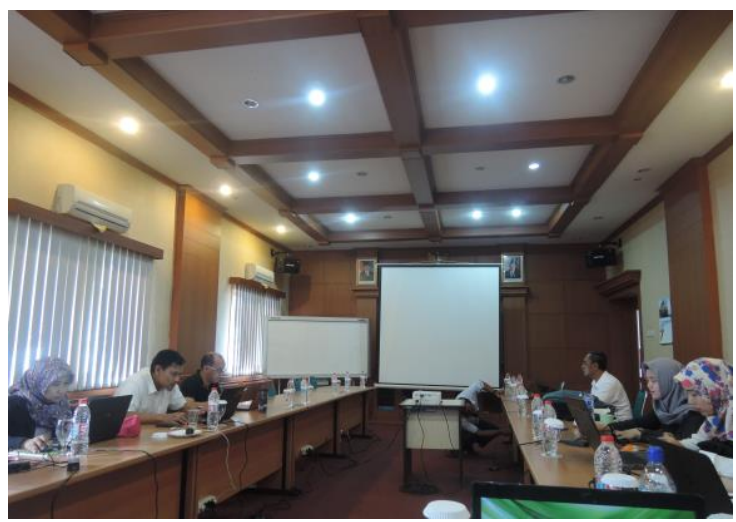

Fig. 6. The atmosphere along environmental incubation program.

This incubation is one of sustainable agenda in order to improve the in charge person behavior and competency. For the last 12 months, incubation already conducted 4 times, and still continues to the next [8].

\section{B. Energy Efficiency: Solar Cell Utilization}

As a power generation company, GSU of Priok generates electricity for people's demand, and also to be used for GSU's operational. It consists of power supply for main operational area (central control room, workshop, etc.) and for administration building (office, etc.).

Having considered the sustainable electricity generation along with environmental dedication, GSU of Priok has energy conservation program in Solar Cell Utilization [9]. This program aims to reduce the internal power consumption, which generated from non-renewable energy sources, by using alternative energy. One of the solar panel that has 
already been installed depicted in Fig. 7.

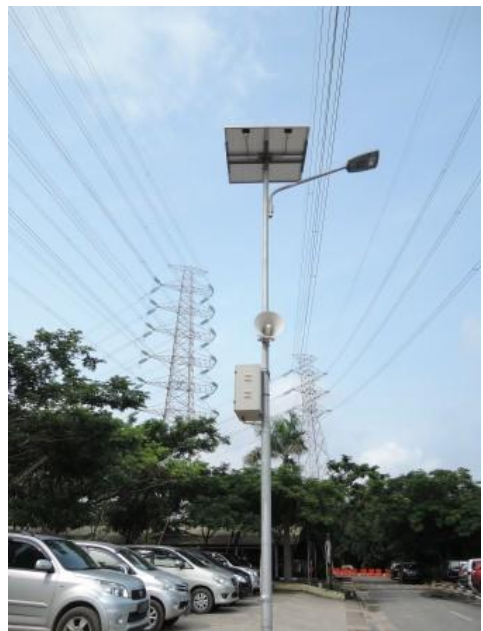

Fig. 7. Solar cell utilization in front parking area of Priok CCPP site

Indonesia, particularly Jakarta Area has a plenty sunshine over year, due to it is one of tropical country. It proves that solar cell utilization is certainly possible to be applied. This utilization program has effectively implemented since 2014, as it shown in Fig. 8.

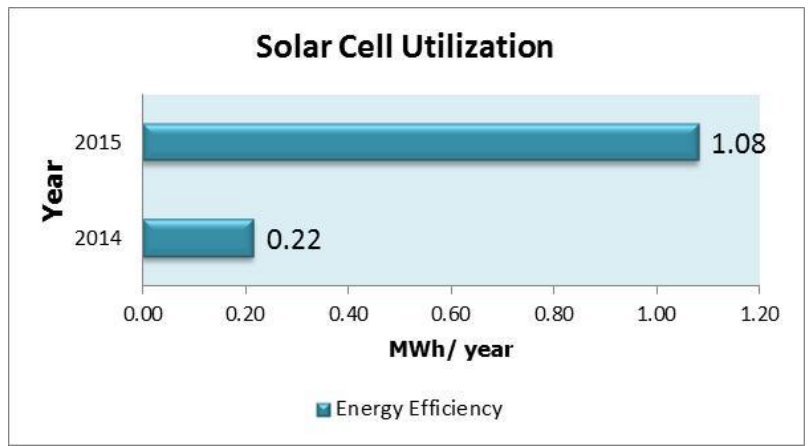

Fig. 8. Energy efficiency on solar cell utilization.

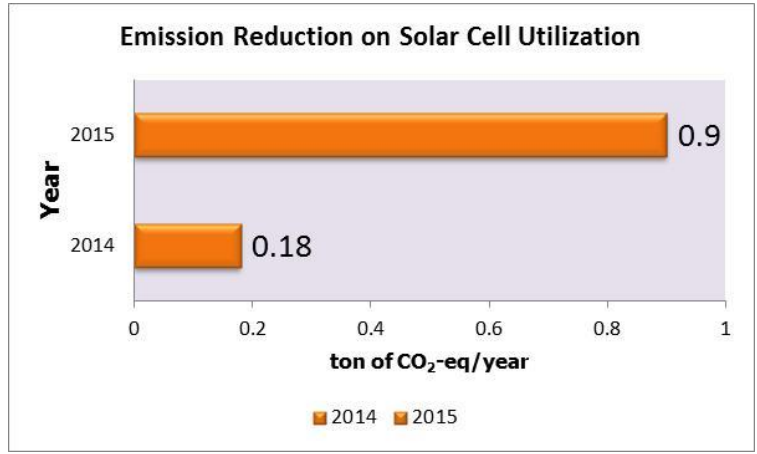

Fig. 9. Calculated emission reduction on solar cell utilization.

Based on Fig. 8., it has shown that by implementing solar cell utilization, GSU of Priok can reduce internal power consumption about 1.08 MWh in year of 2015 [10]. As in 2016 , solar cell utilization has increased and still on progress to the installation.

\section{Emission Reduction: Energy Efficiency Contribution and Priok Vehicle-less in Red Zone Area}

Energy Efficiency Contribution to Emission Reduction

Energy conservation program is contributable to emission reduction, regarding to the source of its emission. One of energy efficiency program shared in this paper is Solar Cell Utilization. Emission reduction calculated by carbon footprint of GSU of Priok activity, as depicted in Fig. 9.

As Fig. 9 shown the calculated emission reduction of energy efficiency program, it is known that for the past two years, total of emission reduced by this program approximately 1.08 ton of $\mathrm{CO}_{2}$-eq [10]. Detail calculation on this program are not discussed in this paper.

\section{Priok Vehicle-less in Red Zone Area}

Other program correlated to emission reduction effort came from field operational vehicles. In GSU of Priok, there are two main zones, White Zone that accessible for employees and visitors, while Red Zone that has a limited access for visitors due to its possible of harm potential. As per 2011, GSU of Priok's has committed to gradually reduce the vehicular emission by culturing use of bicycles to overall employee [10]. One of operation-employees activity on Red Zone depicted on Fig. 10.

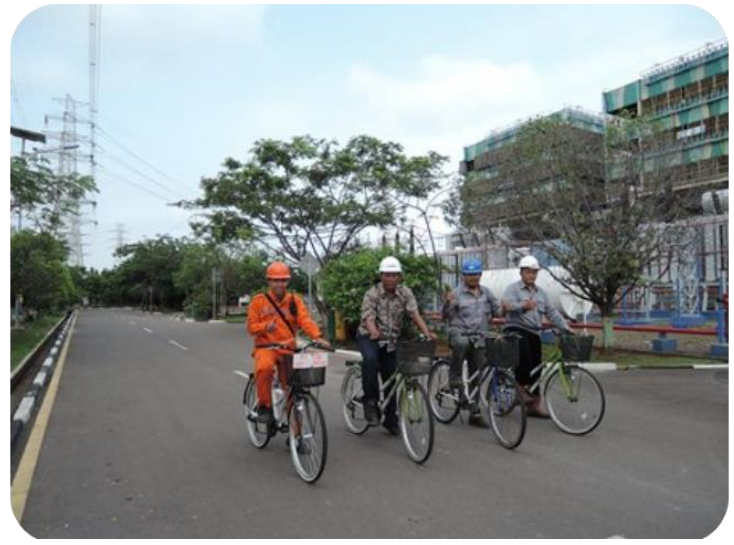

Fig. 10. A harmony between power operation and environmental commitment reflected on the use of bicycles.

Considering the motor vehicle replaced by bicycle on the Red Zone, GSU of Priok has to accommodate the consequences, such as additional parking lot. It is shown in Fig. 11 .

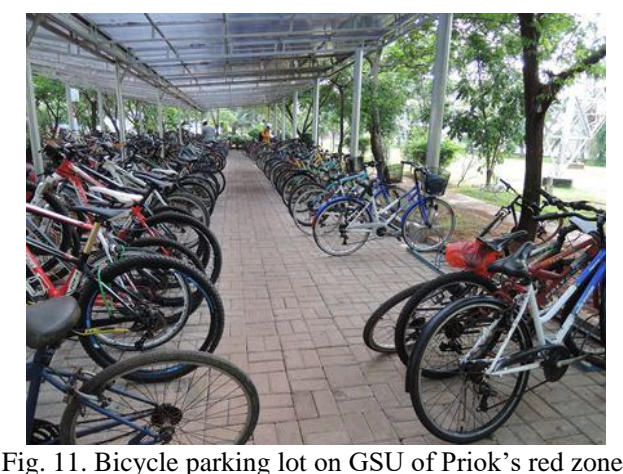

For the past five years, use of bicycle has become a culture in GSU of Priok. It was the other positive impact, while is also contributed to emission reduction as figured in Fig. 12.

It can be inferred from Fig. 12 that the vehicle-less program is not significantly contributed to the global emission reduction. At least it's a fundamental effort on improving environmental awareness among employees.

\section{Replacement of Freon as Refrigerant as Operational}

\section{Support}

Air pollution control has many programs both essential for main operation and support. Another program regarding to emission reduction is the use of Eco-Friendly Freon as 
refrigerant for power generation support [10]. This program will be published on the future publication, taking into account periodical replacement.

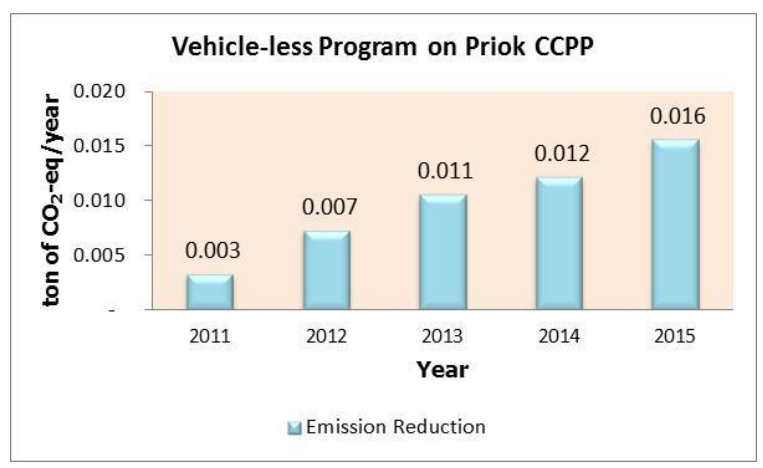

Fig. 12. A triumph of bicycle program in GSU of Priok.

\section{Hazardous Waste Management: Utilization of WWTP Sludge for Mixture Ingredients of Paving Block}

Power plant activity has many possible source of hazardous waste potential. One of activity resulting hazardous waste in GSU of Priok generated from sludge drying bed unit at Wastewater Treatment Plant. At least 200 $\mathrm{kg}$ of sludge has generated per year. Since 2015, we consider to utilize that sludge using solidification methods [11], [12].

Prior to apply the utilized waste to the environment, we have planned several periodical actions. It started from testing hazardous characteristics in 2015, such as Toxicity Characteristics Leaching Procedure (TCLP) and Lethal Dose 50 (LD-50), in collaboration with accredited laboratory. The result shows that LD-50 of Priok's sludge contains 20,271 $\mathrm{mg}$ of substance per $\mathrm{kg}$ of body weight. According to Government Regulation 101/2014 [13], Appendix II Point 6.b., the LD-50 results indicates that the sludge is hazardous waste category II [14].

The next ongoing action is to collaborate with reputable university particularly to determine the best composition of paving block. It has started in first quarter of 2016, which resulting number of physical composites as it shown in Fig. 13.

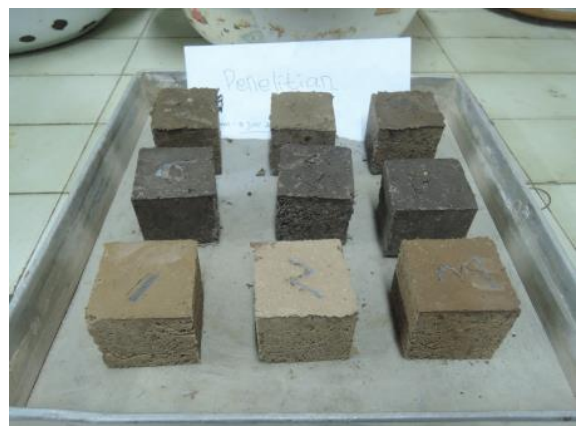

Fig. 13. First solid composites resulted from mixture of WWTP sludge and other materials. Photograph was taken in structural and materials testing

laboratory, Civil Engineering Department - University of Indonesia.

As figured on Fig. 13, collaboration between structural laboratory from reputable university and GSU of Priok has resulted its first solid composites after doing numerous of trials. At the beginning of the program, we have planned to combine the WWTP sludge with green mussel shells from coastal area near site of Priok. It turns out that neither sludge nor the shells itself are not possible to solidified as a mixture ingredients of paving block, unless they are combined. After very time consuming for laboratory trials, it found out that only combinations between sludge and shells is possible to continue to the advances materials testing [15]. Other tests are still on progress and will be discussed in the future publication.

\section{E. Municipal Solid Waste Management from Stream of Kali Japat: From Domestic Waste to Organic Compost for Endemic Plants of Betawi}

Water Intake Facility, however, has a multi-functional purpose aside from its support from operational power generation system. In Jakarta Area, particularly in Priok CCPP Site, it has also a daily function to dredge tons of domestic waste. About $600,000 \mathrm{~kg}$ per year of municipal waste has been screened in this facility for the last two years [16]. It is considered as a lot of waste as a consequence of growing population in this capital city. The situation in this facility depicted in Fig. 14.

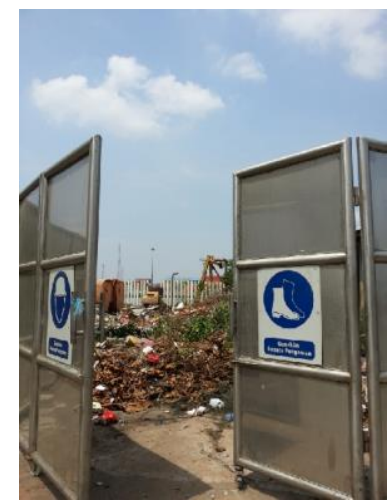

Fig. 14. Screened Jakarta's domestic waste in Kali Japat Water Intake facility.

According to this situation, GSU of Priok has taken action to transform domestic waste into eco-friendly product such as compost from organic waste and plastic waste as non-organic. However, this paper only discussed about composting activities, which located in Priok Site. This program acknowledged and supported by related government and local community as it shown in Fig. 15.

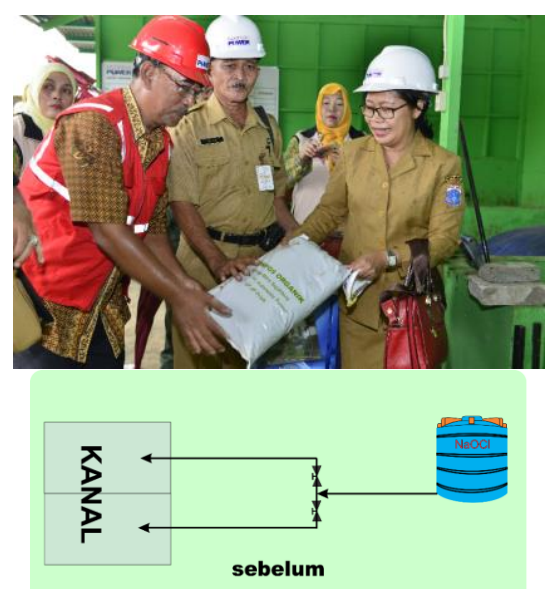

Fig. 15. Packaged compost that made of organic material from Jakarta's municipal waste. Situation was taken place at House of Composting - Priok CCPP Site, at environmental education and visual stimulation program [17]

For land application, the packaged compost has been applied to support endemic plant of Betawi plantation 
program [18]. It was located in Setu Babakan, Jagakarsa - the Cultural Heritage of Betawi. One of endemic plant that used our compost product depicted in Fig. 16.

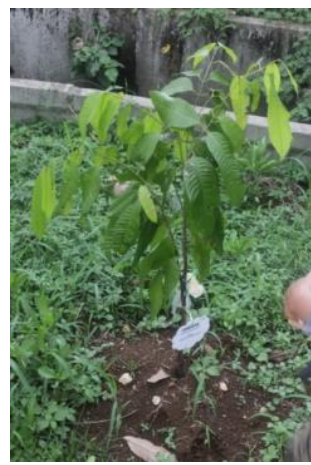

Fig. 16. Endemic Crop of Betawi - Gandaria Tree (Bouea macrophylla) with home-produced compost by GSU of Priok.

It is very interesting that our program to conserve the environment has connected among environmental aspects. As it shown in Fig. 14 to Fig. 16, that a mountain of Jakarta's domestic waste can support the growth of Jakarta's endemic plant, within a small step to managed the waste and turn it into home-processed compost.

\section{F. Water Efficiency: Utilization of Ablutions Water for Plant Watering}

One of domestic water demand in Priok CCPP used for ablution, as a routine during duty-hours about three times per day per person. Since year of 2012, water efficiency team has modified the pipeline system of ablutions water in order to directly use it for plant watering around Priok's Mosque. This program has been saved domestic water used about 100 $\mathrm{m}^{3}$ in 2015 [19]. Activity of this program depicted in Fig. 17.

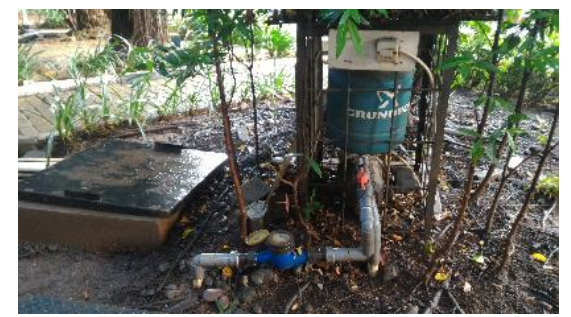

Fig. 17. Flow-meter and installation of ablutions water utilization for plant watering in Priok area.

\section{G. Reduction in Wastewater Load: Replacement of $\mathrm{NaOCl}$ as Biocide in Water Intake of CCPP 1-2}

A biocide can be defined as a chemical or micro-organism that has ability to prevents, controls, and/or renders harmless organism through chemical or biological means. It can be added to other materials to protect them against biological infestation [20]. In Water Intake Facility, Priok CCPP used $\mathrm{NaOCl}$ as a biocide with disadvantage of the amount which leads to a huge risk on chemical handling and required bigger storage facility. This situation has triggered our operation team to replace the biocide of $\mathrm{NaOCl}$ within amine-based biocide, which more effective and efficient. However, the amine-based biocide has a higher cost compared to $\mathrm{NaOCl}$. Chemical injection system that has been modified in water intake facility depicted in Fig. 18.

This amine-based biocide has effectively reduced organic load, chlorine, to the stream about $75 \%$ as per year of 2015
[21].

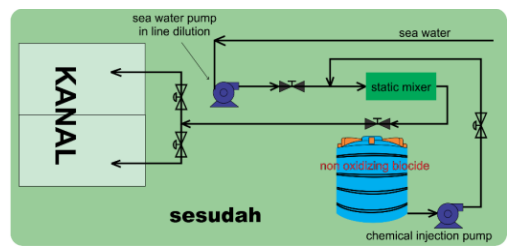

Fig. 18. Modification system (Top: Before; Bottom: After).

\section{H. Biodiversity Conservation: 1920 Endemic Crops Plantation in Setu Babakan - A Cultural Heritage of Betawi}

At the beginning of this year, environmental team incubation concluded with several programs. One of them focused on biodiversity conservation by introducing a Cultural Heritage of Betawi as an icon of Jakarta. According to that, GSU of Priok decided to contribute on biodiversity conservation, in this case endemic crops plantation in Setu Babakan [18]. It has sustainable plan to develop the green space with 1,920 endemic crops, which inspired by a number of the total installed capacity. The landscape view of plantation zone then depicted in Fig. 19.

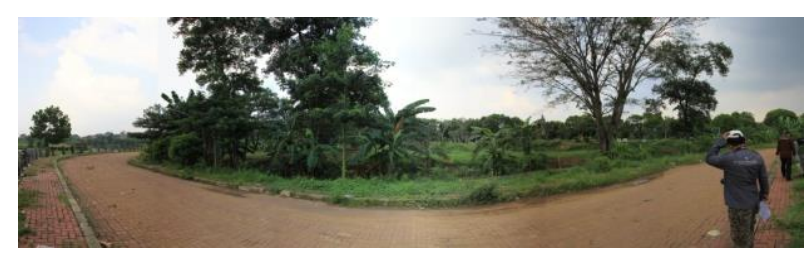

Fig. 19. Landscape view of endemic crops plantation area.

TABLE I: LIST OF ENDEMIC CROPS - Planted IN SETU BABAKAN [22]

\begin{tabular}{|c|c|c|c|}
\hline No & Local Name & Latin Name & Famili \\
\hline 1 & Alkesa & Pouteria campechiana & Sapotaceae \\
\hline 2 & Bisbul & Diospyros discolor & Ebenaceae \\
\hline 3 & Boni & Antidesma bunius & Phyllanthaceae \\
\hline 4 & Cempaka & Michelia alba & Magnoliaceae \\
\hline 5 & Duku & Lansium domesticum & Meliaceae \\
\hline 6 & Gandaria & Bouea macrophylla & Anacardiaceae \\
\hline 7 & Gowok & Syzygium polycephalium & Myrtaceae \\
\hline 8 & Jamblang & Eugenia caryophyllata & Myrtaceae \\
\hline 9 & Jambu Mede & Anacardium occidentale & Anacardiaceae \\
\hline 10 & Jengkol & $\begin{array}{l}\text { Archidendron } \\
\text { pauciflorum }\end{array}$ & Fabaceae \\
\hline 11 & Kebel/Burahol & Stelechocarpus burahol & Annonaceae \\
\hline 12 & Kecapi & Sandoricum koetjape & Meliaceae \\
\hline 13 & Kokosan & $\begin{array}{l}\text { Lansium domesticum } \\
\text { var. aqueum }\end{array}$ & \\
\hline 14 & Lobi-Lobi & Flacourtia inermis & Flacourtiaceae \\
\hline 15 & Manggis & Garcinia mangostana & Clusiaceae \\
\hline 16 & Menteng & Baccaurea racemosa & Phyllanthaceae \\
\hline 17 & Mundu & Garcinia dulcis & Clusiaceae \\
\hline 18 & Rambutan Nona & Nephelium lappaceum & Sapindaceae \\
\hline 19 & Rambutan Rapiah & Nephelium lappaceum & Sapindaceae \\
\hline 20 & Rukem & Flacourtia rukam & Flacourtiaceae \\
\hline 21 & Salam & Syzygium polyanthum & Myrtaceae \\
\hline 22 & Sawo & Achras zapota & Sapotaceae \\
\hline 23 & Sirsak & Annona muricata & Annonaceae \\
\hline 24 & Srikaya & Annona squamosa & Annonaceae \\
\hline 25 & Tanjung & Mimusops elengi & Sapotaceae \\
\hline
\end{tabular}

For the first stage, 30 crops has been planted, which consist of 25 endemic species of Betawi (see Table I). We have conducted the environmental baseline study in collaboration with reputable university. For the maintenance of plantation zone, we work together with local community, 
and supervised regularly by Priok's in charge person. This first step program has been launch formally by the end of April, together with Earth Day of 2016 [18]. It is also supported by government of environmental sector (Ministry of Forestry and Environment - KLHK; Environmental Agency of Jakarta Province - BPLHD DKI Jakarta) together with cultural and tourism sector (Unit Pariwisata dan Kebudayaan DKI Jakarta).

We believe that successful of biodiversity conservation is not solely contingent on ecological perspective, but also incorporate human behavior[23]. Therefore it requires understanding of the social science as conservation program based local community. We consider that stakeholders support is the key success of social-based program and implementation.

\section{Community Development: Local Community}

Empowerment of North Jakarta - Kampung Sehat

As part of Corporate Social Responsibility (CSR), community development plays important role on empowering local society [24], [25]. In community development, which charity is not taken into account, GSU of Priok has initiated an integrated community empowerment program of North Jakarta by mid-August 2015 [26]. It is known as Kampung Sehat (Healthy Village), as it strategically planned to focus on fundamental aspects of health. Health on Kampung Sehat, however, considered in wide perspective, such as hygiene, sanitation, education, health facility, the environment, and economic point of view.

This paper discussed one of Kampung Sehat activity that emphasis to the environment [27], which known as Jimpitan Sampah. This program inspired by Bank of Waste (Bank Sampah) concept, with a light modification. In Jimpitan Sampah, domestic waste (source-based) were selected upon its economics value, such as plastic bottle, etc. (see Fig. 20). It is then collected by local youth organization together with non-productive community to determine the next waste treatment, such as composting for organics, and for non-organic waste with remain-economics value will be trade to waste collectors. Benefit from the waste itself has an objective for regional development, in this case Kampung Sehat - North Jakarta [26].

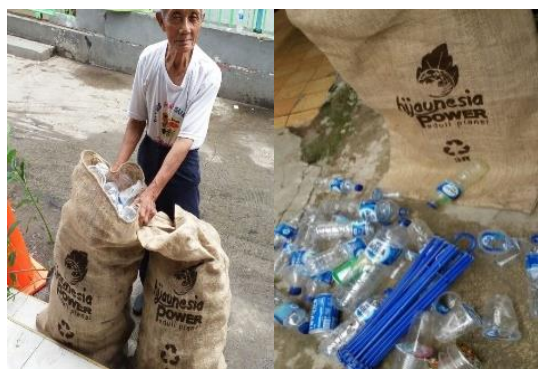

Fig. 20. Jimpitan Sampah activity (left - non-organic waste with remain-economic value; right - local community empowerment for waste collection)

The 10 Innovative Program, as we introduced in this paper, most of them already applied a half-decade and still blossoming with innovative idea in environmental aspects. It turns out with a very interesting result that waste from rural activity can be very useful to the environment by bringing a little effort on it. We believe that by implementing
Environmental Management System, the substantial impact to the environment can possibly reduce. Communication and continuous improvement is the most influenced basic principle in harmony of environmental dedication and electricity generation.

\section{CONCLUSIONS}

The result of these environmental innovative programs concludes that commitment and communication plays important part. Social engagement, taking into account employee and stakeholders (government, local community, university, etc.) is also a part of sustainable improvement. However, overall programs mentioned in this paper are still ongoing which required periodical evaluation. Further studies and updating publication are possible in the future.

\section{ACKNOWLEDGMENT}

We wish to thank to the environmental management and community development team for a very cooperative and quick response. We also would like to thanks our stakeholders, especially to the local community of North Jakarta and Setu Babakan Cultural Heritage Community, and governments (Ministry of Environment and Forestry, Regional Environmental Management Agency of DKI Jakarta Province, Local Government Agency of North Jakarta, Sanitation and Landscaping of North Jakarta, Cultural and Tourism Department of DKI Jakarta, etc.) for all supports and participation through all the innovative programs we applied annually.

\section{REFERENCES}

[1] B. Atiglan and A. Azapagic, "An integrated life cycle sustainability assessment of electricity generation in Turkey," Journal of Energy Policy, vol. 93, pp. 168-186, 2016.

[2] G. Li, R. Zhang, H. Chen, T. Jiang, H. Jia, Y. Mu, and X. Jin, "Security-constrained economic dispatch for integrated natural gas and electricity systems," Journal of Energy Procedia, vol. 88, pp. 330-335, 2016.

[3] N. B. D. Thi, C. Lin, and G. Kumar, "Electricity generation comparison of food waste-based bioenergy with wind and solar powers: A mini review," Journal of Sustainable Environment Research, 2016.

[4] Anonymous, Peraturan Menteri Lingkungan Hidup RI 03/2014 Tentang Program Penilaian Peringkat Kinerja Perusahaan dalam Pengelolaan Lingkungan Hidup, Regulatory Framework on Environmental Compliance, Indonesia : Jakarta, 2013, pp. 1-10.

[5] Anonymous, PROPER Publication 2015, Result and Formal Release of PROPER under Ministry of Environment and Forestry, Indonesia: Jakarta, 2015, pp. 1-88.

[6] Cahyadi, Questionaire Analysis and Report of Environmental Talk Show 2016 - Progress Report on EMS Assistance GSU of Priok, Indonesia: Jakarta, 2016, pp. 1-3.

[7] D. Permatasari, EMS Program and Implementation - Report on EMS Assistance Phase II of PT Indonesia Power GSU of Priok, Indonesia: Jakarta, 2016, pp. 1-9.

[8] D. Permatasari, Focus Group Discussion and Environmental Incubation - Report on PROPER Assistance Phase I of GSU of Priok, Indonesia: Jakarta, 2016, pp. 1-8.

[9] D. Permatasari, Energy Efficiency Program and Implementation Report on Energy Efficiency Assistance Phase II of GSU of Priok, Indonesia: Jakarta, 2016, pp. 1-3.

[10] D. Permatasari, F. E. Putranto, Y. Hidayat, M. J. Saputra, M. Syai, M Saifuddin, Wakhidin, and D. Setiawan, Best Practice on Energy Efficiency and Emission Reduction - Preparation and Presentation of Green Boiler Project in Collaboration with Ministry of Environment and Forestry, Indonesia: Jakarta, 2016, pp. 1-24.

[11] B. Vacenovska, V. Cerny, R. Drochytka, B. Urbanek, E. Vodickova, J. Pavlikova, and V. Valko, "Verification of the possibility of 
solidification product made of neutralization sludge use in the building industry," Journal of Procedia Engineering, vol. 57, 2013, pp. 1192-1197.

[12] J. Hodul, B. Dohnalkova, and R. Drochytka, "Solidification of hazardous waste with the aim of material utilization of solidification products," Journal of Procedia Engineering, vol. 108, pp. 639-646, 2015.

[13] Anonymous, Peraturan Pemerintah Republik Indonesia No. 101 Tahun 2014 Tentang Pengelolaan Limbah Bahan Berbahaya dan Beracun, Government Regulatory Framework on Hazardous Waste Management in Indonesia, Indonesia : Jakarta, 2014, pp. 1-233.

[14] Anonymous, Report of Analysis of WWTP Sludge by PT Sucofindo, Analysis for GSU of Priok, Indonesia: Jakarta, 2015, pp. 1-2.

[15] E.T. Sutiono, E. Arijoeni, D. Permatasari, and A. M. Gantini, Progress Report on Formula Analysis of WWTP Sludge and Green Mussels for Paving Block Mixture — A Logbook Activity for GSU of Priok, Indonesia: Depok, 2016, pp. 1-4.

[16] A. N. Harindrati, Wartono, and F. Setiadi, Solid Waste Management Report on Kali Japat Facility — PT Indonesia Power GSU of Priok, Indonesia: Jakarta, 2016, pp. 1-4.

[17] D. Permatasari, A. Nadjamudin, Wartono, and A.N. Harindrati, Solid Waste Education and Visual Stimulation Report - Report on Solid Waste Management Assistance Phase II of GSU of Priok, Indonesia: Jakarta, 2016, pp. 1-9.

[18] D. Permatasari, F. Setiadi, and F. Alvian, Endemic Crops Plantation in Setu Babakan Jakarsa: Cultural Heritage of Betawi - Report on Earth Day Evaluation for PT Indonesia Power GSU of Priok, Indonesia: Jakarta, 2016, pp. 1-4.

[19] A. Arif and Y. Yanti, Water Efficiency Program of GSU of Priok - A Progress Report on Environmental Assistance Phase II, Indonesia: Jakarta, 2016, pp. 1-2.

[20] Anonymous, "Biocide standards reference guide," Accu Standard, European Union (EU), 2014, pp. 1-36.

[21] A. Arif, Y. Yanti, and A. Mukhid, Biocide Replacement Program - A Progress Report on Environmental Assistance Phase II, Indonesia: Jakarta, 2016, pp. 1-3.

[22] T. Husodo, Environmental Baseline Study of Setu Babakan Progress Report for PT Indonesia Power GSU of Priok, Indonesia: Bandung, 2016, pp. 1-8.

[23] M. Blicharska, E.H. Orlikowska, J. Roberge, and M. Grodzinska-Jurczak, "Contribution of social science to large scale biodiversity conservation: A review of research about the Natura 2000 network," Journal of Biological Conservation, vol. 199, pp. 110-122, 2016.

[24] R. D. D. Putra and B. Rudito, "Planning community development program of Limbangan traditional market revitalization with social mapping," Journal of Procedia - Social and Behavioral Sciences, vol. 169, pp. 143-150,2015.

[25] J. Crawshaw and M. Gkartzios, "Getting to know the island: Artistic experiments in rural community development," Journal of Rural Studies, vol. 43, pp. 134-144, 2016.

[26] T. Wijayanti, N. Sumiasih, and T. Rahman, Community Development of PT Indonesia Power GSU of Priok - A Progress Report on Environmental Assistance Phase II, Indonesia: Jakarta, 2016, pp. 1-4.

[27] S. Kerdsuwan, K. Laohalidanond, and W. Jangsawang, "Sustainable development and eco-friendly waste disposal technology for the local community," Journal of Energy Procedia, vol. 79, pp. 119-124, 2015.

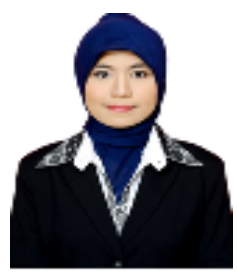

Dewi Permatasari was born in Bandung, West Java, Indonesia. Dewi is the best graduate on her bachelor degree, with latest master degree education on Faculty of Mining and Petroleum Engineering Institut Teknologi Bandung.

She joined solid waste reduction project in Surabaya by Unilever Indonesia. She also has had some research on clean development mechanism. She is very strong on environmental analysis, The EIA project was Sungai Penuh and Hululais Geothermal Project, feasibility study of Kamojang V development, EIA document for Karaha Bodas II \& III, owned by PT. Pertamina Geothermal Energy. During her study on ITB, she became trainer about geothermal environment for PT. Pertamina Geothermal Energy (BPS Pertamina), Chevron, Star Energy under USAID Indonesia - ITB - Star Energy - USC Training for Trainers. Since August 2013, Dewi joined Renewables Power Generation Company as Professional Environment and CSR Advisor, then promoted to Head Office to assist overall Business Unit in achieving environmental compliance and beyond. Most currently, Dewi works as Environmental Advisor in the Biggest Combined-Cycle Power Producer in Indonesia, and also hired in one of the most prestigious building management in Greater Jakarta Area.

Permatasari is one of selected Senior Reviewer of The International Academic Forum - Asian Conference on Sustainability, Energy and The Environment 2015, held in Japan.

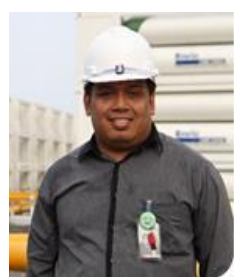

Flavianus Erwin Putranto was born in Yogyakarta Indonesia, on February 24, 1976. He graduated from bachelor degree of Mechanical Engineering, Gadjah Mada University, Yogyakarta.

He has joined PT Indonesia Power for more than 14 years. Currently, Erwin is Operation Manager of PT Indonesia Power - Natural Gas Combined-Cycle of Priok (GSU of Priok). During his duty, he has created many achievements, such as The Best Presenter of Tiara Reliability User Conference (TRUC - 2010), 4 achievements at Museum Rekor Pembangkit (MURKIT) PT Indonesia Power Generation Business Unit of Bali - Gas-Fired Power Plant of Gilimanuk (2010), and Technical Session Presenter of CEPSI (2012). Erwin also became Top 5 Teaching Manager Competition (PMM - OPI) by PT PLN (Persero) in 2014. Others achievement during his dedication in NGCC Priok has brought NGCC Priok as Best 5S Role Model (in 2013) and achieved Zero Accident Award from Ministry of Manpower and Transmigration (in 2014).

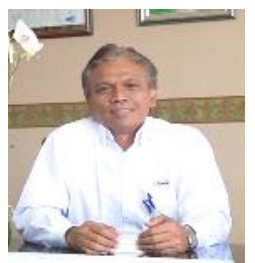

Ir. Tri Tjahjonoputro was born in Pasuruan, Eas Java, Indonesia, on November 19, 1966. He graduated from bachelor degree of mechanica engineering, Institut Teknologi Sepuluh Nopember, Surabaya. He is also graduated from master degree of mechanical engineering, University of Indonesia

He has joined PT Indonesia Power for more than 22 years. His current position is General Manager of PT Indonesia Power - Generation and Service Unit of Priok, the Biggest Combined-Cycle Power Producers in Indonesia. He has also several achievements during his duty, such as Engineer of the Year (Maintenance Service Unit - 2002), Green PROPER (for Perak-Grati Generation Business Unit - 2014), the Highest Green PROPER (Priok Generation and Service Unit-2015), etc.

Ir. Tjahjonoputro, MT., awarded Zero Accident appreciation (in 2015 and 2016) from Ministry of Manpower and Transmigration, Republic of Indonesia. 